\title{
The Legal Protection of Indonesian Physicians: The Medical Dispute Settlement Based on Principles, Standards, Normsand Rules of Physicianprofession in Doctor-Patient Relationship
}

\author{
Setyo Trisnadi \\ The Doctoral Program at the Faculty of Law \\ Sultan Agung University, Semarang, Indonesia \\ setyotrisnadi65@hotmail.com
}

\begin{abstract}
Many malpractice cases in Indonesia attract the public attention. Adoctor always has been regarded as a person who must take responsible for those cases. The legal consequence, he or she mostly is sued in court or becomes a suspect by the criminal charge, without any investigation of the context of malpractice. The lawsuit, both theprivate and criminal law, is a improper legal effort. The doctor is practitioner armed with the code of ethics, thus if there is a infringement, it should be held session of the code of conduct by the Honorary Board of Medical Discipline Ethics or Majelis Kehormatan Etika Kedokteran (MKEK). It hardly can be said that there is no infringement, there is no professional misconduct. The purpose of this article is to make the ethical pathway based on principles-standards-norms-rules and the algorithm infringement of medical profession. It is also to construct law as integration in making justice and fairness for doctors and patients.
\end{abstract}

Keywords: malpractice, medical dispute settlement, medical profession.

\section{INTRODUCTION}

Malpractice cases in Indonesia attract the public attention and sometimes the public makes many opinions that tend to marginalize the position of the doctor as a perpetrator of malpractice. ${ }^{1}$ Then, the perpetrator should be filed in a lawsuit or become a suspect of a criminal case. This creats a prepotition without any analyzing and investigating the substance of the case.

In the criminal case, if the malpractice has occurred and doctors must be convicted due to the negligence because their patients die, furthermore, they are prosecuted by the public prosecutors. Otherwise, a doctorscan be sued by against the law or onrechtmatige daad according to the civil law system, known as unlawful act (tort law)according to the common law system, because his patient suffers losses or even defect to be a reason to file a lawsuit to the court. Kerry J Breenet.alstate "doctors who fail to adequately inform their patients about their condition, treatment options or material risks of treatment may be sued on the grounds of negligence". ${ }^{2}$ Michael G. Faure emphasizes that the today many patients file a lawsuit to the court with the argument of negligence for damage or compensation, or even in some cases become the resposibility of the insurance company granted by the court. ${ }^{3}$

The doctorsare practitioner armed with the code of ethics, deemed to have been perfect and could not make mistakes in their profession, particularly the medical profession, however, it should be stressed also that "the doctorsare also human being", they arenot infallible. What kind of consequences when they work in accordance with the standard medical treatment, evidently, unplanned injury suffered by patients is occured, whereas they have been working according to the standard and compentence.

The medical dispute generally is expressed with a legal relation (rechtsbetrekking) that involves between doctor and patient. The relation creates a deal in the contractual relation wherein the doctor

\footnotetext{
${ }^{1}$ http://www.merdeka.com/peristiwa/5-kasus-malpraktek-dalam-dunia-kedokteran.html, accessed on August $5^{\text {th }}$, 2015.

${ }^{2}$ Kerry J. Breenet.al, Good Medical Practice Professionalism, Ethics and Law, Cambridge University Press, New York, 2010, p. 49.

${ }^{3}$ Michael G. Faure, Accident Compensation, in Elgar Encyclopedia of Comparative law, Edited by Jan M. Smits, Cheltenham,Edward Elgar Publishing Limited, UK, 2006, p. 11.
} 
receives honorarium from the patient and he or she must give his or her medical service. ${ }^{4}$ In the private law, it evokes an agreement to do something or not to give something, as known wanprestasi (default). ${ }^{5}$

Particular in medical practices, the agreement obliges or command the parties to respect based on trust and good faith. It demands honesty that the patient must reveals a variety of things and tell the doctor related with the treatment or healing, including privacy, while the docter being honest helps the patient. ${ }^{6}$

For instance, the case of DewaAyuSasiaryPrawani and her colleagues was begun with an malpractice allegation in a Caesarean section that took the life of patient, Siska Makatey, in Kandauw Malalayang Manado General Hospital. The three doctors were charged with negligence resulted in the death of others(aanwiensschuld de dood van eenandertewijten)as stipulated in Article 359 Paragraph (1) of the Indonesian Criminal Code (abbreviated as KUHP) for negligence resulting in death, this article gives a mixumum sentence of five years's imprisonment, in conjuction with Articel 55 Paragraph (1) and Article 76 of Act No. 29 of 2004 on Medical Practice (the Medical Practice Law).In the first trial, the Manado District Court of declared them free of charges (vrijspraak), ${ }^{7}$ then, but the public prosecutor filed a cassation appeal(in cassatiebrengen) with the Supreme Court and accused them to be jailed for 10 months. ${ }^{8}$ Ultimately, the convicts filed a petition for judicial review. The Supreme Court granted the review and overturned a sentence imposed them. Thus the Supreme Court's justice granted by anulling the judex factie verdict, returning it to the verdict delivered in the first trial. ${ }^{9}$

Departure form the legal issue above, the theme is about the legal protection of Indonesia Physicians in the medical dispute settlement based on principle, standard, norm and rule of Physician's profession in Doctor-Patient Relationship.

\section{DisCUSSION}

\subsection{Doctor-Patient Relationship}

In general, an agreement is laid down in Article 1320 of the Indonesian Civil Code (abbreviated as KUHPerdata). The article declares in order to be valid, an agreement must satisfy the following four condidtions: 1) there must be consent of the individuals who are bound thereby; 2) there must be capacity to enter into an obligation; 3) there must be a specific subject matter; and 4) there must be permitted cause. In continental legal thinking, a person generally has a free choice of entering or not entering an agreement. Marzuki points out that the person is free to decide with whom he/she/it enters the agreement, select what thing to be the subject matter of agreement, and set up what conditions shoul be. ${ }^{10}$

The docter-patient relationship is not merely a agreement ruled by the Article 1320. It is more specific than the general contractual or agreement must be consented by the parties both written and unwritten. The relationship reflects the good faith and moral value. Its legal format is known as Informed Consent (IC). The consent is an agreement of medical treament approved by the patient self or his or her family, if the patient is unconscious or in a state of guardianship, and the doctor.

Pursuant to Jessica W. Berget.al, the IC derives from the legal doctrine operationally. The doctrine enacts in all American juridisctions that it is provided by a doctor legally before he is entitled to hand

\footnotetext{
${ }^{4}$ According to Max Young, a contract is "an agreement (usually between two persons) giving rise to obligations on the part of both persons which are enforced or recognised by law", see Max Young, Understanding contract law, Routledge-Cavendish, New York, 2010, p. 7.

${ }^{5}$ R. Setiawan, Pokok-PokokHukumPerikatan, BinaCipta, Bandung, 2004, p. 17-18.

${ }^{6}$ Ari YunantoandHelmi, Hukum Pidana Malpraktek Medik Tinjauandan Perspektif Medikolegal, PenerbitAndi, Yogyakarta, 2010, p. 13.

${ }^{7}$ The verdict of the Manado District Court No. 90/PID.B/2011/- PN.MDO, see http://www.thejakartapost.com /news/2014/02/14/doctors-apologize-patient-s-death.html, accessed on October 10, 2015.

${ }^{8}$ The verdict of The Supreme Court No. 365 K/PID/2012.

${ }^{9}$ The verdict of the Judicial Review No. 79 PK/PID/2013, see http://nasional.tempo.co/read/news/2014/ 02/07/055552090/supreme-court-overturns-court-decision-on-dr-ayu, accessed on October 10, 2015.

${ }^{10}$ Peter Mahmud Marzuki, An Introduction to Indonesian Law, Setara Press, Malang, 2011, p. 237.
} 
a patient's medical treatment. Its term of conditions consist of two part of the legal obligation, among others, firstly the doctor gives information to the patient and secondly the doctor provides an counseling before the administrative. In fact, it becomes a landmark which emerges such attention through the legal optic and ethic when the patient is harmed, and the doctor is then filed by a lawsuit. In other words, this indicates legal certainty. Consequently, the IC contains specific legal requirements in the medical treatment prescribed in clauses, butthe patient isstill entitled to information about the clauses. ${ }^{11}$

The existence of IC was emerged with a case of Schloendorff v. Society of New York Hospital. It could be said that "every human being of adult years and sound mind has a right to deter mine what shall be done with his body". The caseemphasized a concept of voluntary consent that a patient freely gives permission for the special treatment to him or her self. It also became a step forward from the simple agreement with the indentified conditionsbeforehand when that agreement without the patient's will was assumed as well as there was no consent at all. ${ }^{12}$ During the next decades there was some litigation regarding IC.

In 1995, The Nort Carolina Supreme Court declared that the failure to explain the surgery risks was considered to become a mistake of the surgeon. Two years later, the case Salgo v. Leland Stanford Junior University Board of Trustees, Carolina court by the precedent of the court ruling itself that a doctor had a responsibiltiy to inform the surgery risks. In the nex year, The Minnesota Supreme Court strengthened the responsibility. The decision asserted that the physician was responsible for providing information to patients on the unpexted surgery risks before the operation and the informaion became a alternative form of accountability that not listed in the the approval procedure. Thus, ther is an modern evolution of the IC not only implies the treatment clauses but also the information is given to the patients regarding riks, benefits and other aspects other aspects as a result of treatment or care. ${ }^{13}$

While several court recently has been charged the resposibility to the doctors in order to give the information about risks, benefits, other aspects other aspects as a result of treatment or care compared to the previous view that did not require them. The New York court passed a decision on the doctor's responsibility for a mental patient because the doctor did not give information about the condition and the appropriate treatment to the patient. ${ }^{14}$

In the Salgo case, the Court has been faild to give the detailed and explicitly statement in connection with the disclosure what should be impose by the doctor. The Court ruling brought Salgo as plaintiff to file appeal based on the court's instruction that the obligation of doctors should give information to the patients about the risks that will be suffered as a result of the operation. ${ }^{15}$

The doctrine found in the Salgo case was possibly a significant case in the in the mid-1950s, particularly due to creating IC. This case involved a patient who sufferes translumbar aortographyearly method of aortography by injection to the aorta through a needle just below the twelfth rib and four fingerbreadths to the left of the spinous process of the vertebra ${ }^{16}-$ leg paralysis, a strange disease but not including complications. The patient suspected among the complaints that he suffered, that insufficient information was given to him not listed in the procedure. Based on the case, the court made a rule that a doctor violated his duty to the patient and obligation to him self if he hid every fact which should be informed to the patient to form the basis of an intellegent consent. ${ }^{17}$

Along with that case above, in colaborating the doctrine of IC, Court declared that the juries should order doctor having a consitent discretion to keep a patient's personal health in accodance with the medical confidentiality as one of the core duties of medical practice, of course, however the full

\footnotetext{
${ }^{11}$ Jessica W. Berget al, Informed Consent Legal Theory and Clinical Practice, $2^{\text {th }}$, New York : Oxford University Press, 2001, p. 12.

${ }^{12} I d$, p. $43-44$.

${ }^{13} \mathrm{Id}$.

${ }^{14} I d$.

${ }^{15} \mathrm{Id}$.

${ }^{16} \mathrm{http}: / /$ medical-dictionary.thefreedictionary.com/translumbar+aortography, accessed on October 15, 2015.

${ }^{17}$ George Pappas, Informed Consent: A Malpractice Headache, Chicago-Kent Law Review, Vol. 47 Issue 2, January 1970, p. 247.
} 
disclosure of facts was necessary to be ruled in IC. Thus, the Salgo case also focusses on the doctor's discretion to keep the personal health as known therapeutic exception. Although courts develops term of conditions of IC, they are doubt to give a kind of mandate regarding the full disclosure to the patients. ${ }^{18}$

Departure from Jay Katz's observation, the case substantially gives a contribution solving existed problems and then regarding the term of conditions in the doctrinal IC. Because of this case, Salgo strives to unite two contradictive opinions. ${ }^{19}$ Jay Katz says that "Only in dreams or fairy tales", he also hangs in the balance "can 'discretion' to withhold crucial information so easily and magi cally be reconciled with 'full disclosure". ${ }^{20}$

Salgo, however, creates a definite stability resulting a idea of obligation to the doctors to disclose the term "IC" that is useful for the development of law. Thereby this new term does not give progress in law as a big thing. This moment gives legal consequences to Courts for three year to start systematize the doctrine of IC.

Two cases have been emerged in early 1960 after Salgo namely Natanson v. KlinedanMitchell v. Robinsno.In the caseof Natanson, a woman suffered severe enough burns to do chest X-ray of radiotherapy after mastectomy. Otherwise, in the case of Mitchell, the plaintiff received insulin snobs and electro shock therapy for the treatment of schizophrenia that causes fracture of several vertebrae). In both cases, the patient's consent for treatment had been supplied, however the doctors had been having obligation firmly to disclose information due to the risks of treatment, although conversly the obligation was not to be done and assumed as a infringement of negligence. ${ }^{21}$

The regulation of IC in Indonesia is stipulated in Act No. 29 of 2009 on Medical Practice, particular in consent of medical or dental measure. Article 45 of Medical Practice law prescribes as follows:

- every medical act performed by the medical or dental practitioner to the patient must gain the consent;

- the consent as defined in paragraph (1) will be given after the patient has obtained the full clarity;

- the clarity as stipulated in paragraph (2) includes at least:

- diagnosis and procedures for medical act;

- the purpose of undertaken medical act;

- another act for alternatives and risks;

- the risks and complications that may occur; and

- Prognosis of the taken act.

- the consent as defined in paraghrap (2) can be performed by way of both written and verbal;

- every high risk act performed by the medical or dental practitioner must be given with the written consent signed by whose the right has to give the consent.

- the provision concerning procedural of medical act performed by the medical or dental practitioner as defined in paragraph (1), (2), (3), (4), and (5) shall be made by the Minister Regulation.

According to Elucidation of Article 45 paragraph (1), one who has the right to give the consent or refusal of medical service is patient. But, if the patient is under guardianship (ondercuratele) the consent or refusal can be approved by his or her relatives such as husband/wife, biological

\footnotetext{
${ }^{18}$ Jessica W. Berget al, Op.cit, p. 44-45.

${ }^{19}$ Jay Katz points out that"Since Salgo, the requirement of "consent" in malpractice law has purportedly given way to "informed consent". The new legal hybrid's two components-disclosure and consent-have been given unequal treatment in case law. While the disclosure component has received some construction, the consent component was left un-touched; in fact the doctrine ofinformedconsentstraddlestwo bodies of law "informed", denoting recent changes in negligence law, and "consent", representing the law ofmedical battery, unchanged for decades", see Jay Katz, Informed Consent-A Fairy Tale? Law's Vision, University of Pittsburgh Law Review, Vol. 39 Issue 137 Year 1977, p. 143.

${ }^{20}$ Jessica W. Berget al, Loc.cit.

${ }^{21} I d$.
} 
father/mother, biological children or sibling. Moreover, meanwhile the patient is conscious or in a good state, he or she shall immediately be given with the clarity and made with the consent. In the case of patients are children and unconscious man, accordingly the clarity must be given to the relatives or someone who brings the patient to the hospital. If there is no one who brings the patient to there and there is no any relative, conversely the medical care must immediately be taken that the clarity shall be given patient's biological children or on the first opportunity the patient is conscious.

Elucidation of Article 45 paragraph (3) states that it is hoped the patient should be given in an understandable language because the clarity is a basic to give consent. Another aspect should also be given to the patient regarding clarity related to financing. Elucidation of Article 45 paragraph (4) emphasizes that the verbal consent in this article is an approval given in the form of a agree statement or a nod (an up and down movement) of the head difined as it. While, as defined in Elucidation of Article 45 paragraph (4) "every high risk act" is like sugery or another invasive service.

Article 51 regulates obligation of the physician or dental practitioner in the medical practice, as follows:

- give medical care in accordance with the Medical Professional Standards (MPS), Medical Standard Operating Procedures (MSOP), and also medical needs of patients;

- referring a patient to another medical or dental practitioner who has better expertise or ability, if the physician is not able to carry out examination or treatment;

- the duty of confidentiality to hold everything which he knows about his patient, to continue even after a patient has died;

- perform emergency care on the basis of humanity, unless if surely there are not other people in charge and not able to do so; and

- enhance knowledge and follow the development medical or dental sciences.

Rights and obligations of patients are prescribed in Article 52 and Article 53, respectively in receiving of medical service on the medical practice. The patients have rights as follows

- obtain a full description of medical act according to in Article 45 paragraph (3)

- ask the opinion of another medical or dental practitioner;

- obtain services in accordance with medical needs; and

- refuse the medical act;

- obtain the contents of the medical records.

The patients have obligations in receiving of medical service on the medical practice, as follows:

- provide complete and truthful information about health problems;

- obey to advice and instruction of the medical or dental practitioner;

- comply with regulatory requirements in the health care facilities; and

- provides fee for the received service;

The basic pattern of doctor-patient relationship, according to Szas and Hollander, rely upon circumstances of patient's social and cultural disease, as follows: ${ }^{22}$

\section{Activity-Passivity}

This patter occurs on the patient who his or her life is threatened or being unconscious, or suffers serious mental illness (SMI). The therapy pattern persists in a state of patient's helpless.

Guidance-Cooperation

${ }^{22}$ Ari YunantodanHelmi, Op.cit, p. 15-16. 
The guidance-cooperation is like a relation between parents and their children. This cooperation occurs when a patient's condition is not too heavy, such as an new infection or other acute illness. On the one hand the patient is being sick, he remains conscious, has feelings and his own will. He tries to seek a aid treatment and will have a cooperation. On the other hand, the doctor knows more; he does not merely carry out the authority, but expects the patient's cooperation realized with the advice and recommended.

\section{Mutual Participation}

The basic philosophy of this approach is based on consideration that every human being has equal dignity and rights. It ocuurs on those who want to maintain good health by conducting the medical check-up or patients who suffer chronic diseases such as hypertension or diabetes mellitus. They are conscious and have active role in their treatment. or family

\subsection{Code of Medical Ethics}

The ethical dimension in connection with the doctor-patient relationship takes a lot of attention. Doctors must always consider carefully. They are aware of their limits. Pursuant to March Stauch, however it is not always in the practice, they ideally ought to eschew them selves form speculativeand risky actions. This is well known as primum non nocere (first, do no harm) and also as the Hippocratic Oath. Patients should respect the doctor's assessment and advice in a way not to criticize and meet all requirements. A hope of recovert is a reasonable, but they have a little choice except that they he continues to obey the assessment and advice.

Hope for recovery is a reasonable patient, but the patient has little choice but to remain, according to the assessment and advice of a doctor. ${ }^{23}$ The Hippocratic Oath contains anything related to the professional practice of doctors or vice versa.Hippocrates saw, heard and underwent man in his life which would not be necessary discussed at length. In his oath, he always would patient maintain confidentialityand recommendate all should be kept secret. ${ }^{24}$ According to Sidharta, in general, the code of medical ethics consists of moral principles attached to a profession and systematically compiled but it does not mean without any ethical code every professional shall forward those principles adhered to his soul. ${ }^{25}$ Furthermore, the profession is a moral community armed with common ideals and values. The code of professional ethics could be assumed as a monopoly of profession, notwithstanding, it exactly gives a sense of trust in the social. K. Bertensunderlines the code be a compass to point at moral goals for a profession and also to secure a good quality of moral profession to the public. ${ }^{26}$

In Indonesia, the ethical value of doctor is explicity outlined in Indonesian Code of Medical Ethics or KodeEtikKedokteran Indonesia (KODEKI). Its provisions have been revised to adjust the current development. ${ }^{27}$ The KODEKI embodies the value of normative ethics, that is "what ought to be" or "what should be done", called Das Sollen. In other words, it should not be overriden by something beyond it. From the normative point of view, it is equal to the legal principle having contents of normative matter characterized as Das Sollen.

The KODEKI comprises norms which should be an obligation not only to be said out loud in the taking of an oath but also upheld, understood and practiced by medical practitioners. In according with K. Bartens, moral characteristics of the medical profession appeared in the Indonesian Doctor Oath especially with a phrase "Sayaakanmembaktikanhidupsayagunakepentinganperikemanusian" or "I will devote my life to thehumanitarian interests". Moreover, K. Bertens define the phrase as a value of the philosophical foundation and as a extraordinary phrase contains an emphasis on the humanitarian side. ${ }^{28}$ This side brings basic moral into reality of the ethical profession in order that

\footnotetext{
${ }^{23}$ Marc Stauch, 2008, The Law of Medical Negligence in England and Germany A Comparative Analysis, Hart Publishing, Oxford And Portland, p. 3.

${ }^{24}$ Myrtle R. Flight, 2010, Law, Liability, and Ethics for Medical Office Professionals, Fifth Edition, Delmar, Cengage Learning, United States of America, p. 180.

${ }^{25}$ Sidharta, 2009, MoralitasProfesiHukumSuatuTawaranKerangkaBerpikir, RefikaAditama, Bandung, p. 107.

${ }^{26}$ K. Bertens, 2011, Etika, Gramedia Pustaka Utama, Jakarta, p. 298-299.

${ }^{27}$ AgusPurwadianto, et. al, 2012, KodeEtikKedokteran Indonesia, Pengurus BesarIkatan Dokter Indonesia, Jakarta, p. 1-2.

${ }^{28}$ K. Bertens, Op.cit, p. 37.
} 
doctors are obliged to give aid or help to patients without any discrimination. They are beneficence, non maleficence, justice and respect to patient's autonomy. In addition, they should also be guided by the applicable operational standards.

\subsection{Medical Dispute}

The legal problem solving concerning docter-patient relationship includes three legal dimensionals inter alia administrative, private and criminal law. In casu, a doctor is alleged to do a malpractice and this is not fair that he must to be jailed or is sued in court as defendant without any deep investigation to the case.The demensionals help us for this case.

Firstly, the dispute shoul be settled through the administrative law as premium ultimatum. The legal problem solving will be carried out through the hearing of code of medical ethics. As far as a doctor has performed his duty in accordance with causes of malpractice in the medical practice espoused by the absence of the four indications i.e. of Medical Professional Standards (MPS), Medical Standard Operating Procedures (MSOP), Informed Consent (IC), medical needs of patients and also code of medical ethics initiated by The Indonesian Honorary Board of Medical Discipline or MajelisKehormatanDisiplinKedokteran Indonesia (MKDKI).The board should take over the case from the court.If the trial of the board declares there is a professional misconduct but it is still in the scope of the four indications, the doctor then can be dismissed from his practice, conversely if there is no professional misconduct, he is be freed from quilty administratively. The doctor, hence, continues his medical practice as well as usually.Instead, all the Assembly of the board consideres that the doctor has violated MPS and MSOP, then the doctor could face administrative sanctionsi.e.disciplinary sanctions as prescribed in Article 69 Paragraph (3) Act No. 29 of 2009 on Medical Practicesuch as written warning, recommendation for revocation of Certificate of Registration (Surat Tanda Registrasi) or PracticeLicense (Surat Izin Praktik); and/orobligation to follow education or training in medical or dental educational institutions.

Secondly, if the board stated that a doctor has violatedSPK and SOP, he or she could be imposed with administrative sanctions. The board' decision could be an evindence for filling a private lawsuit by a patient in the form of a default in contract or tort law through an unlawful act (onrechtmatigedaad). Thedefault in contract lawsuit is based on Article 1320 and 1243 of KUHPerdata stresses that an agreement or contract such as IC must be fulfilled by the debtor to the creditor. The agreement or contractsuch as IC is a contractual legal relationship. Thus a doctor can be sued by the a patient based on the IC as the agrement of contract that could not fulfilled. At the other side, the unlawful lawsuit based on 1365 KUHPerdata underlines that a doctor has commited unlawfull act because his act is a violation of laws and contrary to the principle of decency, accuracy, and circumspection (kepatutan, ketelitian, dan kehati-hatian abbreviated as PATIHA) be expected in association with fellow community (liabilty in accordance with laws). ${ }^{29}$

The medical consent, also known astherapeutic transaction agreement (abbreviated as TTA) or (perjanjiantransaksiterapeutik) is dealed with 1) there must be consent of the doctor and patient who are bound thereby; 2) there must be capacity of the doctor and patient to enter into an obligation; 3 ) there must be a specific subject matter i.e. a medical service; and 4) there must be permitted causei.e. a medical service is not contrary to legal norms. From the four terms of conditions is the second term mainly focused on the patient's capacity based on Elucidation of Article 45 of Medical Pratice Act.

In general, thedefault in contracttakes place because of three matters among others: 1) a debtor does not meet achievementsentirely; 2) a debtor does notfilfull achievements overdue; and 3) The fulfillment of achievements of a debtor is not good. ${ }^{30}$ Meanwhile, a medical profession is a profession characterized with the medical service. This profession have two elements, among others: 1) to apply a set of systematically arranged knowledge of the problematics of the specific problems; and 2) those problems have important relevance in accordance with the fundamental values considered by the community. ${ }^{31}$

\footnotetext{
${ }^{29}$ S. Soetrisno, 2010, MalpraktekMedik\&Mediasi, Telagallmu Indonesia, Jakarta, p. 8.

${ }^{30}$ R. Setiawan, 2004, Pokok-PokokPerikatan, BinaCipta, Bandung, p. 19-20.

${ }^{31}$ Titik Triwulan Tutikdan Shita Febriana, 2010, Perlindungan Hukumbagi Pasien, Prestasi Pustaka Publisher, Jakarta, p. 47.
} 
The three conditions to determine a doctor has commited a breach of theTTA, among others: 1) a doctor does not meet achievementsentirely in TTA; 2) a doctor does notfilfull achievements overdue in TTA; and 3) The fulfillment of achievements of a debtor is not good in TTA.

The unlawful lawsuit is based on Article 1365 KUHPerdata. This Article points out that every unlawful act that causes damage ontoanother person obliges the wrongdoer tocompensate such damage. To state that a doctor would be the wrongdoer in the malpractice, there must filfull the four conditions, among others: 1)a patient must suffer a loss; 2) there must be a error or ommision (it is also imposed to the hospital to take a responsibility due to that error or ommision by its employees such doctors and nurses); there must be a causal relationship (causaal verband) between loss and error or ommision; and 4) the act is unlawful. ${ }^{32}$

A line of demarcation should be drawn between a default in contract and unlawful act (onrechtmatigedaad) in accordance with filing a lawsuit in the court so as to be clear for the basis of claim, whereas the filing can certainly be obscure (obscuur libel) and then declared "admissible" by court or niet ontvankelijk verklaard (NO). S. Sutrisno suggests that the basis of claim between those norms should be separated or exchanged, that is the default in contract emphasizes on the consent of doctor-patient relationship and the unlawful is based on the docter's act that should be guilty according to laws. The applied standard to determine a error or ommision is no more relied on subjective or individualistic nature as well as the wrongdoer is based on the principle of decency, accuracy, and circumspection (PATIHA) of a doctor who is assumed having reasonably ability (redelijkbekwaam). ${ }^{33}$

According to Stolker, an error or ommision element in agreement or unlawful, in fact, often has a little difference. ${ }^{34}$ Rosa Agustina interprets PATIHA that people should have a kind of tolerance with their environment and fellows. Consequently, they are not only concerned with their own interests but also with the interests of others. Furthermore, she also emphasizes PATIHA based on the unwritten law but in its examination still relies on juridical norms which that unwritten law is connected with the principle of legal norms. ${ }^{35} \mathrm{~A}$ human being generally should have a principle of duty of care) in order to be said to do negligence and to harm the others. ${ }^{36}$ In the case of a doctor gives the medical service, therefore, he should implement the principle of duty of care, tolerance and concerning with healing the patient as a human being to get relief not to cause harm and suffering for his patients.

To determine the existing unwritten law in the society what the doctor has committed the unlawful act should cohered with Article 45 concerning agreement, Artilce 51 concerning obligations of a doctor in the medical practie and Article 52 concerning rights and obligations of a patient stipulated in the medical practice Act.

The most natural way to support that legal claims, both a default in contract or unlawful act, is therefore to try to show what right answer is in some particular medical case. I can just do that, surely, by making ordinary legal argument. I argue in fact as a middle way or medium ultimatum. This way also provides an another way, as basic assumption, alternative dispute resolution (ADR) based on consumer protection law. This view, however, presents the two opposing oponions, pros and cons. The pro specifies that professional services such as doctors or lawyers are similar with other business actors like entrepreneurs or trader stipulated in Article 1 Paragraph (2) and paragraph (5) of Act No. 8 of 1999 regarding Consumer Protection. Article 1 Paragraph (2) prescribes: "Consumer is each individual user goods and/or services available insociety, for the benefit of them-selves, family members, otherpeople, and other living creatures and which are not for trading" and Paragraph (5) prescribes: "Services is any service in the form of work or performance tradedin the society to be used by the consumers". On the contrary, the cons asserts that patients are not same with consumers. In

\footnotetext{
${ }^{32} I d$.

${ }^{33}$ S. Soetrisno, $I d$, p. 9-10.

${ }^{34}$ Id.

35 Rosa Agustina, Perbuatanmelawanhukum, dalam Hukumperikatan (Law of obligations)/ Penulis: Rosa Agustinadkk. -Ed.1, 2012, PustakaLarasan, Denpasar, p. 9-10.

${ }^{36}$ MunirFuady, 2013, Perbuatan Melawan Hukum Pendekatan Kontemporer, Citra Aditya Bakti, Bandung, p. 87.
} 
other words, the docter-patient relationship is very unique and complicated. Thus that relationship could totally not be same with the consumer and the business actor in economy. ${ }^{37}$

Thirdly, According to Ari Yunanto and Helmi, malpractice case in criminal law there must be three conditions, namely: 1) inner attitude; 2) medical treatment; and 3) consequence. In essence, the inner attitude is approved with any intention (opzet) or negligence (culpa) i.e act (daad) in the medical service. The medical treatment is an act that deviates from the valid norm. The consequence is emerged to any loss for the patient's health and live. A doctor can be charged with the criminal law due to his act which complies the three conditions becoming a malpractice case relied on KUHP such as Article 359, 361 juncto 55 Paragraph (1) or criminal provisions in the Medical Service Act or Act No. 36 of 2009 regarding Health.in addition, the doctor also can be imposed with the severe criminal law if he could be suspected of serious crimes such as forgery of the practice license, the sale of organs, abortion and so forth.

The three legal demensions above should beforemost begun with through the hearing of code of medical ethicsinitiated byMKDKI or the administrative trial regarding doctors are practioner. The board declares the doctor is not guilty, thus he or she can not be filed a private lawsuit or a criminal charge. Conversely he or she is guilty so the board's decision can be an evindence to file those legal efforts. Particular in the criminal law, a doctor can be a perpetrator if he or she meets three conditions i.e. inner attitude; medical treatment; and consequence.

It must be underlined that the hearing of medical ethic does not suspend the patient's legal efforts either the private law by a lawsuit in court or the crimal law by reporting it to the authority. Those effors are the patient's individual right to sue or accuse protected by law that has been violated by the other i.e. the doctor. In the criminal case, the doctor can be charge with a grievance/complaint or ordinary offense concerning it has been happend a criminal case becoming a responsibility of the legal enforcer especally Police.

Doctors are always be the perpetratorof a medical malpractice by negligence. Inevitably, this statement has been expressed by Kerry J Breenet.al. They said that "doctors who fail to adequately inform their patients about their condition, treatment options or material risks of treatment may be sued on the grounds of negligence" ${ }^{38}$ The same statement was also given by Michael G. Faure. According to him, a lawsuit to the doctor was based on plea of negligence submitted by the patient to the court to obtain restitution or compensation, or also sue the the responsibility of the insurance company, in some cases. ${ }^{39}$

The three legal demensions i.e administrative, private and criminal law are a form of the legal protection of Indonesian physicians. This notion has been expressed by H.J.J. Leenen, et.al, that "Juridische regeling is niet alleen van belang voor de samenleving en de patiënt, maar ook voor de beroepsbeoefenaar zelf. Zij waarborgt zijn professionele zelfstandigheid, geeft hem rechtszekerheid bij het uitoefenen van zijn beroep, beschermt hem tegen ongerechtvaardigde klachten, geeft hem richtlijnen over wat de samenleving hem toestaat of verbiedt, helpt hem beslissingen te nemen en beschermt hem ook tegen zichzelf, bijvoorbeeld indien hij zou worden verleid tot handelen uit andere motieven dan het belang van de patient". ${ }^{40}$

\footnotetext{
${ }^{37}$ S. Soetrisno, Op.cit, p. 17-18.

${ }^{38}$ Kerry J Breenet.al, 2010, Good Medical Practice Professionalism, Ethics and Law, Cambridge University Press, New York, p. 49.

${ }^{39}$ Michael G. Faure, Accident Compensation, dalam Elgar Encyclopedia of Comparative law, 2006, Edited by Jan M. Smits, Cheltenham, Edward Elgar Publishing Limited, UK, p. 11.

40 H.J.J. Leenen, et.al, 2008, HandboekgezondheidsrechtDeel II Gezondheidszorg en recht, Vijfde, geheelherzienedruk, Houten, Bohn Stafleu van Loghum, p. 15. Freely translated: "Legal regulation is not only voor interest of the society and the patient, but also voor de practitioner self. It guarantees his professional independence, gives him legal certainty in the exercise of his profession, protects him from unjustified complaints, gives him guidance on what society allows or prohibits him, helps him to take decisions en and also protects him from himself, for example, if he would be tempted to act from other motives than the interest of the patient.
} 


\section{CONCLUSION}

The three legal demensions i.e administrative, private and criminal law can be applied to malpractice cases. Patients or their relatives can can take the legal efforts through litigation and non-litigation. The litigation can be filed through a lawsuit of default in contract or unlawful act (tort law) in court and also does not rule out the entry into force of the criminal law. The non-litigation can be reached through Alternative Dispute Resolution (ADR) or the MKDI's hearing as the form of administrative law for the medical practitioners.

A new lega argumentation that can be given for the legal protection of the medical practitioners is to apply foremost by the MKD's hearing in recalling the doctors are the practitioners who hold the code of ethics. If a doctor is guilty charged by MKDI and then the MKDI's decision can be an evidence for a private lawsuit or a criminal charge. In other words, a postulat can be cleraly declared that there is no professional misconduct, there is no illegal act.

\section{AUTHOR's BIOGRAPHY}

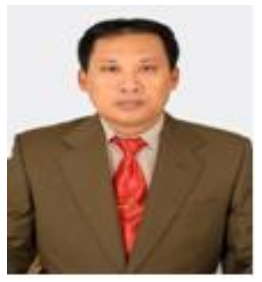

DR. Setyo Trisnadi, Sp.KF, SH., Medical Faculty of Universitas Sultan Agung (UNISSULA), Semarang, Indonesia. Jl. Raya Kaligawe KM 4 Semarang, Central Java, Indonesia.

- Coordinator of Education of Forensic Medical Specialist, Medical Faculty of Universitas Sultan Agung (UNISSULA), Semarang, Indonesia.

- Installation Foresic Medical Doctor, Bhayangkara Hospital, Semarang, Indonesia.

- Chief of Installation Foresic Medical Doctor, Ken Saras Hospital, Semarang, Indonesia.

- Consultant of Forensic Medical Doctor, Telogorejo Hospital, Semarang, Indonesia.

- Deputy Dean I of Medical Faculty of Universitas Sultan Agung (UNISSULA). 